\title{
Children's Rights Urgention in Early Childhood Learning During at Home (Pandemic Covid-19)
}

\author{
Marina Trie Ramadhany Gunawan ${ }^{1,2, *}$
}

\author{
${ }^{1}$ Early Childhood Islamic Education Study Program \\ ${ }^{2}$ STAI Sabili Bandung, Bandung, Indonesia \\ *Corresponding author.Email: marina.trie@staisabili.ac.id
}

\begin{abstract}
This study aims to raise the importance of considering children's rights in planning, creating and implementing early childhood learning while at home in a covid-19 pandemic situation. The problem behind this research is the existence of Allah SWT's command not to neglect to protect and provide children's rights and also the existence of good government regulations or international agreements. In addition, the most important problem is the increase in cases of child abuse during the Covid-19 pandemic. Teaching and learning situations that are new to children and parents place children and their parents in a position that is vulnerable to stress and violence. This study uses a meta-analysis method that examines several sources of scientific journals on children's rights and early childhood learning at home during the pandemic. Based on this research method, the researcher found that it is very important to exercise children's rights during children's learning at home. This is because fulfilling children's rights will help children build self-esteem and develop good character that is useful for children in the future.
\end{abstract}

Keywords: Children's rights, early childhood learning, pandemic covid-19, home, self esteem

\section{INTRODUCTION}

Early childhood education learning is currently experiencing a considerable transition [1]. The transfer of teaching responsibilities to being completely dependent on parents at home is one of the challenges parents must face during the Covid-19 pandemic [2]. Quite a few complaints and problems arose as a result of this sudden situation. However, the child's right to receive education must still be fulfilled by parents.

Every child in the world, which in this case children in countries Indonesia $\mathrm{m}$ emiliki respective rights that must be met. As the mandate contained in Article 28B Paragraph 2 of the Constitution of the Republic of Indonesia which contain s ach child is entitled on the continuity of life, grow and thrive and have the right on protection from violence and discrimination. This mandate leads to the respect and protection of children's rights from all forms of violations that affect the child physically and psychologically.

Children's rights are derived from the human rights listed in the 1945 Constitution of the Republic of Indonesia and the UN agreement on Children's Rights. The UN Agreement on the Children's Rights absolutely affirms the respect and guarantees of the rights of every child without discrimination in any form. Rights of the Child in the agreement the United Nations in 1989, can be summarized into 10 points among which is the right of children to play, the right of children to education, the right of children to protection, the right of children to get the name (identity), child's right to acquire nationality, child rights to obtain food, children's rights to health access, children's rights to recreation, children's rights to obtain equality, children's rights to have a role in developmen [3].

Children are entrusted by Allah SWT. As the hadiths found in the book Bahjatu Qulubil Abrar, which contains:

$$
\text { أولى الناس بِبزَك وأحقهم بمعروفاك أولادك، فإنهم أمانات جطهم الله عندك. }
$$

It means "human beings who foremost get your kindness, and most deserve your good deeds are your children. Because in fact they are a mandate that Allah has put by your side." [4]. By because it's, had become an obligation of the parents to pay attention to and meet the needs of the development of their children . Children's rights are fulfilled can grow into a child are healthy, both physically and spiritually. With the help and guidance of parents and teachers as well as those around the child may have akhlaqul karimah and have intelligence that high .

The obligation of parents or adults around children is not only to look after and educate children. Parents and other adults are also responsible for fulfilling the right of an ak to have the skills of living that is adequate so that the child grow into a capable, competent and strong. So actions such as letting children not receive education, leaving children insecure and allowing hunger are attitudes that lead to violations of children's rights. It should not be allowed because it can cause the child to grow into a child who is not competent, did not have a competent man and expertise da $\mathrm{n}$ can make children become individuals who are weak. Conditions which thus gets a warning loud from Allah , as reflected in the Qur' an Surat An- Nisa ' verse 9,

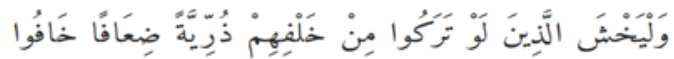




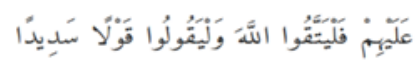

which means "And let fear to God those who are suppose to leave behind their children are weak, that they worry about ( welfare ) them . By because it let them fearing to Allah and let them utter words which true". The verse further emphasizes the obligations of parents and other adults . Parents and other adults need to educate children with the best possible, with attention to talent and interest, so that children can thrive in an optimal [5].

Apart from the religious side, from the point of view of early childhood development, paying attention to children's rights can be a strategy to develop children's life skills. As Law Number 23 Year 2002 Article 2 Paragraph 2 [6] states that children's rights include the right to life, survival and development. As well as Article 2 Paragraph 3 which contains respect for the child's opinion. Fulfilling children's rights by allowing children to take the initiative to express their opinions, carry out negotiations and provide space for children to carry out a democratic process can have a lot of influence on children's character. This is in line with research conducted by Anisah [7], which states that one of the characteristics of good parenting (authoritative parenting) is that parents listen to children's opinions, review children's opinions and then provide suggestions or views. Thus, children will have good self-confidence, a good level of independence and a high sense of respect because parents do not underestimate their opinion.

Respecting the child's right to have an opinion or voice, can also provide a good example or role model for children. Seeing parents who can listen well to their opinions teaches children to follow this praiseworthy attitude when children are exposed to the community. As explained by Rachmanita [8], under one of the good character education of children is the ability to tolerate others. Children who, at an early age, have their right to express opinions recognized by their parents. Potentially doing the same to others. The ability to tolerate includes the ability of children to appreciate things that are considered different from themselves. This includes respecting differences of opinion, to differences that are more physical in nature such as ethnicity, ethnicity, and the attitudes of others.

However, this noble goal is certainly not easy to realize. Especially in difficult times due to a pandemic like the one currently happening in various parts of the world, especially in Indonesia. The Covid-19 pandemic has brought many changes, especially in the field of education [1] . Children who normally study at school must get used to studying at home. This habit also applies to parents. Along with the increasing number of changes during the Covid-19 pandemic, the increase in cases of violations of children's rights has also increased. As recorded by the Online Information System for the Protection of Women and Children (2020), there are approximately 3087 new cases of violence against children. These cases consisted of 857 cases of physical violence, 768 cases of psychological violence, and 1,848 cases of sexual violence. This is also increasingly evident with the news conveyed by Rezkisari [9] , which states that the Covid-19 pandemic has a lot of influence on the relationship between parents and children. Parents who are not ready for the situation of children who have to stay at home and parents who have to be good caregivers cause stress or pressure on the parents. This stress or pressure triggers violence to children at home by their own parents.

In addition to violations of children's rights in the form of violence against children, the fulfillment of children's rights to health services is also less than optimal. Due to the pandemic, many health practices that were opened with certain hours and regulations were even forced to close temporarily. This of course causes the access of parents and children to health to experience limitations. It was noted that in April 2020, the number of children who received complete basic immunization had decreased by 245,661 children compared to April 2019 [10]. In addition, parents who are hesitant to bring their children to health service facilities are also another cause of delays in children's rights to health [11].

In terms of fulfilling the right to participate, there have also been violations of children's rights. The government and schools are competing to create a learning system that can still be implemented by children at home in an online system (in the network). Most early childhood education learning programs designed by governments, schools or teachers do not involve children's voices. This shows the weak fulfillment of children's participation rights. Children should be given the opportunity to express their opinions and desires, but the government's decision to establish a new school year learning for children, which is directly followed by each school indicates the absence of children's participation in the decision making.

The rise of cases of violation of children's rights certainly has an impact on children's survival. Especially when violations of children's rights occur within the scope of early childhood education learning. Children who are not fulfilled their rights will not be able to grow up to be capable and responsible individuals. Even in the worst case, the child's violation of rights will be possible for the child to commit to someone else in the future. For example, a child who is not fulfilled his right to participate or have an opinion can cause the child not to give the opportunity to talk to other people because he feels he has never felt to express his opinion. If teachers and parents only emphasize the implementation of early childhood education learning without paying attention to feelings of pleasure or displeasure from the child, this can cause the child to feel forced and depressed in learning. The coercion and pressure experienced by the child can cause the child to stress and hurt the child mentally [12]. When children experience stress, it will be difficult for children to follow planned learning [13]. This can have a bigger impact, especially in early childhood. At an early age, children experience some limited communication with their parents [14]. This is because some parts of the body in children are still immature, such as the tongue, eyes, or the ability to process their emotions. And also the child's ignorance of some life skills that are still in the process of development. So the potential for greater stress experienced by early childhood. 
Based on the background of these problems, the authors intend to discuss the importance of children's rights in learning early childhood education at home during the Covid-19 pandemic.

\section{RESEARCH METHOD}

This paper uses a meta-analysis methodology. The metaanalysis in this research is a series of methods analyzing previous research on children's rights and early childhood learning at home during the pandemic. The methodology of the meta-analysis itself is a process of examining and discussing by means of analyzing, reviewing various scientific works related to children's rights and early childhood learning at home during the pandemic that has existed from previous research [15] and conditions that changed during the pandemic. The research begins with formulating research problems and objectives, then searching for the latest research results relevant to the chosen theme (children's rights in early childhood learning at home during the Covid-19 pandemic). This article analyzes some previous research on child rights and early childhood learning at home during the pandemic (Covid19).

\section{RESULT AND DISCUSION}

\subsection{The importance of children's rights in early childhood learning}

Learning early childhood education is one of the most important parts in the process of early childhood development. Early childhood education learning is a series of activities designed to help children prepare for further education. In addition, to help children achieve skills and aspects of development. Activities designed in early childhood education learning will be in direct contact with children. So these activities should be arranged properly. Making good learning activities depends on how the process of planning these activities is. Home learning should begin to lead to a change in the planning process. This is because of the various possibilities and limitations currently faced by children and parents during the Covid-19 pandemic . Learning at home is a new condition, both for parents and children. It is imperative that the lesson plan that is prepared is also updated according to the current needs of the children.

The child's current need is learning that can still be fun even though the child has to go through the process at home. In addition, given the explanation previously stated, that during the Covid-19 pandemic there was an increase in cases of violence against children. Where this case of violence certainly violates children's rights. So one important point of view that must be considered by the maker of learning planning for early childhood is the fulfillment of children's rights during learning . Children's rights must be a major consideration, especially when early childhood learning occurs $100 \%$ at home [2]. So that children can still fulfill their rights, and parents can properly fulfill their obligations to fulfill children's rights during the learning process.

Children's rights are important to be considered in the learning process. $\mathrm{T}$ idak simply because regulation alone, but also for the sake of terw ujudnya prosperous individuals and unseen [16] [17]. Child welfare can be realized when learning is structured by taking into account the important points of children's rights. This is in line with the opinion of Budiyanto [18] that in an Islamic perspective, one of the rights that must be fulfilled by parents to their children is the right to welfare. That way, it is increasingly clear that when learning at home is carried out by parents by paying attention to children's rights, the parents have carried out one of their obligations in the eyes of Allah SWT.

Another reason is that a children is an investment $i$ the future of the nation [19]. In order to prepare capable and skilled individuals in the future, the fulfillment of children's rights in providing learning stimuli at this time must be considered. In addition, the learning that is currently being received by children will affect the next child's development [20] . When structured learning fulfills children's rights, children's development can be optimized. That is why it is important to pay attention to children's rights when arranging children's learning activities.

\subsection{The principle of children's rights in implementing early childhood learning}

One principle in designing activities for early childhood learning based on children's rights is to create a childfriendly learning environment. Child-friendly learning environment means to condition the learning situation by prioritizing children 's opinions and activeness. In addition, child-friendly learning situations must be in the form of situations that are healthy, safe, fun, cheerful and especially respect for children's rights [21].

Creating activities for child-friendly learning can be in the form of fun activities such as telling stories, talking about children's hobbies or inviting children to imagine and be creative to visit a place that children like [22] [23]. By providing fun activities for children, children's rights to play, children's rights to education and children's rights can be respected.

Furthermore, the principle of making early childhood learning planning based on children's rights is to see children as agents or subjects and as active individuals [24]. 
Viewing children as agents or subjects and active individuals can help planning learning for children to be more sensitive to children's roles in the learning process. So that the existing activities are offers for giving or even orders [25].

The third principle to make early childhood learning with attention to children's rights is to involve children's participation. As explained by [26] that one of the dimensions of social justice to fulfill children's rights is to implement the dimension of participation. In $\mathrm{d}$ im ensi participation, the child's voice to be one important component in the planning and implementation of learning. All activities to be arranged and offered to children must be based on the views and views of the children. Therefore, it is very important to gather information and interact intensively with children. This is an effort to find learning that is comfortable and safe and appropriate to the wishes of the child. So that it will not violate the child's right to be respected or heard.

\subsection{Benefits of the concept of children's rights in early childhood learning}

It has been explained previously about the importance of children's rights and the principles of children's rights in implementing early childhood learning at home during Covid-19 based on children's rights. B erdasarkan explanation-p enjelasan it has seemed that include the rights of children as one of the considerations for designing a child's learning at home is one of the important efforts to fulfill the rights of children in accordance with international regulations and the state [6][3]. In addition, there are several benefits that can be obtained for both parents and children, if you consider children's rights in learning while at home. As for some of these benefits, namely:

First, when learning has been implemented with due regard to children's rights, children will learn with joy and joy. As has been explained in the Qur'anic verse, chapter Al-Kahfi Verse 46 which reads:

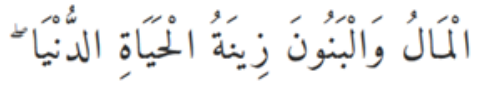

The meaning is "Treasure and children are jewelry of the world". Seeing this verse, it is clear that children are one of Allah's precious entrants. Parents must be able to care and nurture the children, so that their children are always happy and excited. With a happy and excited mood, helping children to more easily accept and develop learning stimuli. So that aspects of child development can be managed more optimally.

The second benefit when making early childhood learning with attention to children's rights can help children grow into capable and good character individuals. As explained by [27], one of the strategies that parents can use at home when studying with children is to make children feel loved and respected for their rights. It can make children have a strong foundation of self-esteem. Children have learned that as individuals, they must appreciate and respect the rights of other individuals because other people respect their rights. That way, the good character that has grown can easily be developed by children in social life in the future. In addition to children, the benefits of paying attention to children's rights when learning at home can also be felt by parents. When parents respect children's rights, whether to argue, negotiate or express what they like and don't like, it will be easier for parents to invite children to work together in the daily learning process [28]. Difficulties felt by parents, sometimes because parents do not know what their children really want. Even children are too difficult to express their intentions. Through a learning system that prioritizes children's rights, giving parents and children the opportunity to understand each other.

\section{CONCLUSION}

The conclusion that can be drawn is based on the description of the problems and the above discussion, namely, firstly, there are quite a lot of problems that will arise if parents at home who are currently in charge of educating children neglect children's rights in the learning process at home. Problems that can arise are, for example, children will tantrums, children will be bored, children will be stressed, which results in irritating parents and consciously or not violence against children at home [10]. Seeing these possible problems, it is very important to pay attention to children's rights in the learning process, especially when children or parents are in a difficult transition phase because of Covid-19 as it is today. There are several principles that parents can use when learning children at home, namely creating a child-friendly environment, providing fun and cheerful activities for children, considering children as active individuals who must be given offers not orders and also making learning that can involve children's participation. By paying attention to these principles, the positive implications will be felt by early childhood or by parents. The child becomes in a situation of feeling comfortable, safe and happy. Children can also grow in the process of becoming capable individuals, respecting others and having good character. For parents, of course, it becomes easier to know the feelings and desires of the child. Children and parents can foster an atmosphere of cooperation during learning at home and can increase their attachment. No less important, parents as guardians and protectors of children have carried out their obligations to fulfill children's rights as per the verse of Allah SWT, government regulations and international agreements. 


\section{REFERENCES}

[1] Ayuni, D., Marini, T., Fauziddin, M., \& Pahrul, Y. The readiness of gu ru tk to face online learning during the Covid-19 pandemic . Journal of Obsession: Journal of Early Childhood Education. 5(1) (2020) pp. 414-421

[2] Oktaria, R., \& Putra, P. Education of children in the family as an early childhood education strategy during the Covid-19 pandemic. Pesona PAUD Scientific Journal. 7(1) (2020) pp. 41-51.

[3] Perserikatan Bangsa-Bangsa (PBB). United Nations Convention on the Rights of the Child. New York: PBB, 1998.

[4] Nashir as- S a'di, SA. Bahjatu Qulubil Abrar Wa Qurratu ' Uyunil Akhyar Fi Syarhi Jawami'ul Akhbar . Riyadh, Saudi Arabia: Madar al- Wathan Linnasyir . Accessed online via http://bit.ly/Kitab-Bahjatu-QulubilAbrar-Wa-Qurratu-Uyunil-Akhyar-Fi-SyarhiJawamiul-Akhbar, 2011.

[5] Wahab, R. Keeping children is the trust of Allah. Accessed online on August 1, 2020 via https://arbaswedan.id/menjaga-anak-amanah-allah/, 2020.

[6] Republic Indonesia. Undang-Undang Nomor 23 Tahun 2002 Tentang Perlindungan Anak. Indonesia: Republic Indonesia, 2002.

[7] Anisah, A. S. Pola asuh orang tua dan implikasinya terhadap pembentukan karakter anak. Jurnal Pendidikan UNIGA, 5(1) 2017 p. 70-84

[8] Rachmanita, E. Pembelajaran Mendengarkan Cerita Anak Berbasis Pendidikan Karakter Untuk Mengembangkan Pribadi Siswa. Jurnal Ilmiah Bahasa dan Sastra Unikama, 3(2) 2016 p. 111-121.

[9] Rezkisari, I. Covid-19 dan kekerasan ke anak yang meningkat. Republika. Dapat diakses melalui https://republika.co.id/berita/qbnmuq328/covid19-dankekerasan-ke-anak-yang-meningkat. 2020, June 9.

[10] Yulindrasari, H. Child rights issues during the Covid-19 pandemic. National webinar 'Protection of Children's Rights during the Covid-19 Pandemic, Ambon, Maluku, 2020.

[11] Puspa, A. Immunization of children during the pandemic has decreased. Indonesian media. Can be accessed via https://mediaindonesia.com/read/detail/317748imunisasi-anak-di-masa-pandemi-turun. 2020, June 3.

[12] Field, T. Separation stress of young children transferring to new schools. Developmental psychology. 20(5) 1984 pp. 786

[13] Lieberman, AF, \& Van Horn, P. Psychotherapy with infants and young children: Repairing the effects of stress and trauma on early attachment. Guilford Press. 2011.

[14] Wijayanti, R., \& Akbar, M. R. Assessment of parent coping strategy model for early childhood problems. Journal of Educational Inspiration. 8(1) 2018 pp. 79-83.

[15] Elyasir, H. A. Significance Test in Meta-analysis Approach: A theoretical Review. American Journal of Theoretical and Applied Statistics. 4(6) 2015 pp. 630639.

[16] Ariyanti, T. Pentingnya pendidikan anak usia dini bagi tumbuh kembang anak. Dinamika Jurnal Ilmiah Pendidikan Dasar. 8(1) 2016.

[17] Moore, D., Morrissey, A. M., \& Robertson, N. 'I feel like I'm getting sad there': Early childhood outdoor playspaces as places for children's wellbeing. Early Child Development and Care, 2019 pp. 1-19.

[18] K. Budiyanto, H. M. Children's rights from an Islamic perspective. Journal of IAIN Pontianak, 149 2014

[19] Rasyid, H. Membangun Generasi Melalui Pendidikan Sebagai Investasi Masa Depan. Jurnal Pendidikan Anak, 4(1) 2015.

[20] Briggs, R. D. The importance of social emotional development in early childhood. Pediatrics for Parent. 282012 pp.11-15

[21] Prasetiawan, H. The role of guidance and counseling in child-friendly education in character building from an early age . Journal of CARE (Children Advisory Research and Education). 4(1) 2016 pp. 5060 .

[22] Yulianti, R. (2016). Learning creative dance to improve understanding of environmental love in early childhood. JPKS (Journal of Education and Arts Studies). 1(1) 2016

[23] Kurniawati, Y., \& Setyowati, S. Improving Children's Speaking Ability through Storytelling 
Method with Big Book Media at PPT Tulip Surabaya.

PAUD Teratai. 3(3) 2014

[24] MacNaughton, G. Rethinking gender in early childhood education. Australia: Allen \& Unwin. 2000.

[25] Ananda, R. Implementation of moral and religious values in early childhood. Obsession Journal: Journal of Early Childhood Education. 1 (1) 2017 pp. 19-31.

[26] Barrett, A. M., \& Tikly, L. Quality in education from an international perspective. Bristol, Angleterre: EdQual. 2012.

[27] Hastuti, D. Strategy development of the price of self- child age early. Ahmad Dahlan Primary School Education Journal. 2(2) 2016 pp.38-50.

[28] Grebelsky-Lichtman, T. (2014). Parental patterns of cooperation in parent-child interactions: The relationship between nonverbal and verbal communication. Human Communication Research. 40(1), 2014 pp.1-29. 